\title{
HOW ARE NATIVE VEGETATION AND RESERVES AFFECTED BY DIFFERENT ROAD TYPES IN A SOUTHEASTERN BRAZILIAN STATE?
}

\author{
Simone R. Freitas ${ }^{1,2}$, Cláudia O. M. Sousa ${ }^{2}$, Danilo Boscolo ${ }^{3}$ and Jean Paul Metzger ${ }^{2}$ \\ ${ }^{1}$ Universidade Federal do ABC (UFABC), Rua Santa Adélia 166, Bloco A, Torre 3, sala 631-3, Santo André, SP, Brazil. CEP: 09210-170. \\ ${ }^{2}$ University of São Paulo, Institute of Biosciences, Department of Ecology, Rua do Matão, 321, travessa 14, São Paulo, SP, Brazil. CEP: 05508-900. \\ ${ }^{3}$ University of São Paulo, Faculdade de Filosofia Ciências e Letras de Ribeirão Preto, Departmento de Biologia, Av. Bandeirantes, 3900 - Ribeirão \\ Preto - SP -Brasil - CEP 14040-901 \\ E-mails: simonerfreitas.ufabc@gmail.com, cau.orsini@gmail.com, danilo.boscolo@ffclrp.usp.br, jpm@ib.usp.br \\ Simone R. Freitas (Corresponding author). Universidade Federal do ABC (CCNH). Rua Santa Adélia, 166. 09210-170, Santo André, SP, Brazil. E- \\ mail: simonerfreitas.ufabc@gmail.com. phone: (55) (11) 4437-8379
}

\begin{abstract}
Reducing connectivity, road networks may threaten the effectiveness of natural reserves, thus, representing a critical conservation matter. This work aims to: 1) evaluate the relationship between native vegetation cover and road distance; 2) evaluate the extent to which native vegetation and nature reserves are affected by roads. Our study area was a neotropical landscape in the state of São Paulo, Brazil. We divided the study area into 15 subregions to represent its high heterogeneity. First, we demarcated buffer zones of 10 different distances around each road, and quantified the density of roads and native vegetation cover. Second, we estimated the area ecologically affected by roads, the roadeffect zone, using buffers of increasing distances according to each road type. The most dense road network was found in the São Paulo Metropolitan area and the lowest was the Southern Coastline subregion, but this subregion showed the second highest expressway density. These two subregions had stronger positive relationships between native vegetation cover and road distance. Almost $10 \%$ of São Paulo state, about $6 \%$ of the remaining native vegetation, and more than $10 \%$ of the reserves were ecologically affected by roads. More than $50 \%$ of reserves were ecologically affected, and some have more than $60 \%$ of their territory affected. Threats related to proximity of roads, i.e. logging, may reduce effectiveness of more than $50 \%$ of natural reserves. Thus, we propose that identifying priority areas for integral conservation of pristine environments should include mostly remote areas, which are far from larger roads and under lower general road influence.
\end{abstract}

Key words: conservation; reserve design; road ecology; road-effect zone; tropical landscape.

\section{INTRODUCTION}

Roads are meant to connect cities and urban centres and to provide access and logistic support to different economic activities embedded within several land-use types. These linear infrastructures are arranged and interconnected forming complex networks, which vary in shape and purpose (Forman et al. 2003). However, roads also have important environmental consequences, affecting the atmosphere, soils, native vegetation, fauna and human settlements existing in its vicinities (Forman et al. 2003). For instance, vehicle transported exotic plants can extend to $100 \mathrm{~m}$ from a given road, while traffic noise may interfere with the communication and reproduction of animal populations, especially birds and frogs, living hundreds of meters away from it (Reijnen et al. 1995, Forman and Deblinger 2000). In addition, the presence of roads and vehicles increases wild animal road-kill and the emission of pollutants and other substances that raise the risk of conflagration (Forman et al. 2003, Laurance et al. 2009). As a consequence, the proximity of roads to forest patches may cause increased edge effects, deeply changing the biological richness and composition of forest dwelling communities (Fahrig and Rytwinski 2009, Laurance et al. 2009, Freitas et al. 2012).

However, one of the first and most notorious effects of building a road is landscape fragmentation. This process can cause edge and barrier effects (Murcia 1995, Develey and Stouffer 2001, Forman et al. 2003), reducing landscape functional connectivity (McGregor et al. 2008, Fahrig and Rytwinski 2009), namely the capacity of a landscape to facilitate biological fluxes (Taylor et al. 1993). Road network density may thus influence biological conservation and ecosystem services by permanently bounding environments and ecological processes within insurmountable linear obstacles. Because roads may change the connectivity between animal and plant populations, directly affecting species 
persistence in the landscape, there is a pungent need of understanding the relationships between roads and native vegetation cover, and of evaluating the roadeffect zone that is the area along roads within the limits of the ecological effects on species, soil, and water (Forman 2000).

Understanding how roads may interact with its surrounding environments, creating new landscape mosaics which also include human occupied areas, may thus help both transportation and environmental planning (Dramstad et al. 1996). This would be useful to substantiate the inclusion of road ecology concepts as additional criteria to be considered in the definition of conservation and environmental restoration priority areas. Implementing nature reserves is a worldwide strategy to protect not only endangered species, but also their interactions, habitats and ecosystem processes (Rodrigues et al. 2008).

Within this framework, this study aims to: 1) evaluate the relationship between native vegetation cover and road distance in a neotropical landscape in the State of São Paulo, Brazil; 2) evaluate through a simple categorical concept, the extent to which native vegetation and nature reserves might be affected by roads in this region.

\section{MATERIAL AND METHODS}

\section{Study site}

Our study area was the state of São Paulo, southeastern Brazil (Figure 1). This region has more than 40 million inhabitants and is the most human impacted land of South America. It also has the $6^{\text {th }}$ biggest city in the world - São Paulo city - with more than 11,200,00 inhabitants, densely distributed (IBGE 2010a). The countryside is mainly rural with extensive pastures and agricultural land uses, but there is also industrial and logistic infrastructure and at least 20 medium-sized cities with more than 300,000 inhabitants (IBGE 2010a). The region presently has a dense transportation network, with more than $37,000 \mathrm{~km}$ $\left(0.151 \mathrm{~km} / \mathrm{km}^{2}\right)$, representing $6.3 \%$ of the Brazilian network of unpaved and paved roads (IBGE 2010b; Figure 1) with different sizes and traffic intensity. Most of these roads and highways were built and paved during the 1950s and 1960s following the Brazilian industrial development after the Second World War (Neto 2001, Drummond 2004), but this network continues to increase. For these reasons and because the state presents an effective scale for policy and decision-making, we have chosen the whole state of São Paulo as study site, comprising an area of 248,196,960 $\mathrm{km}^{2}$ (IBGE 2010b).

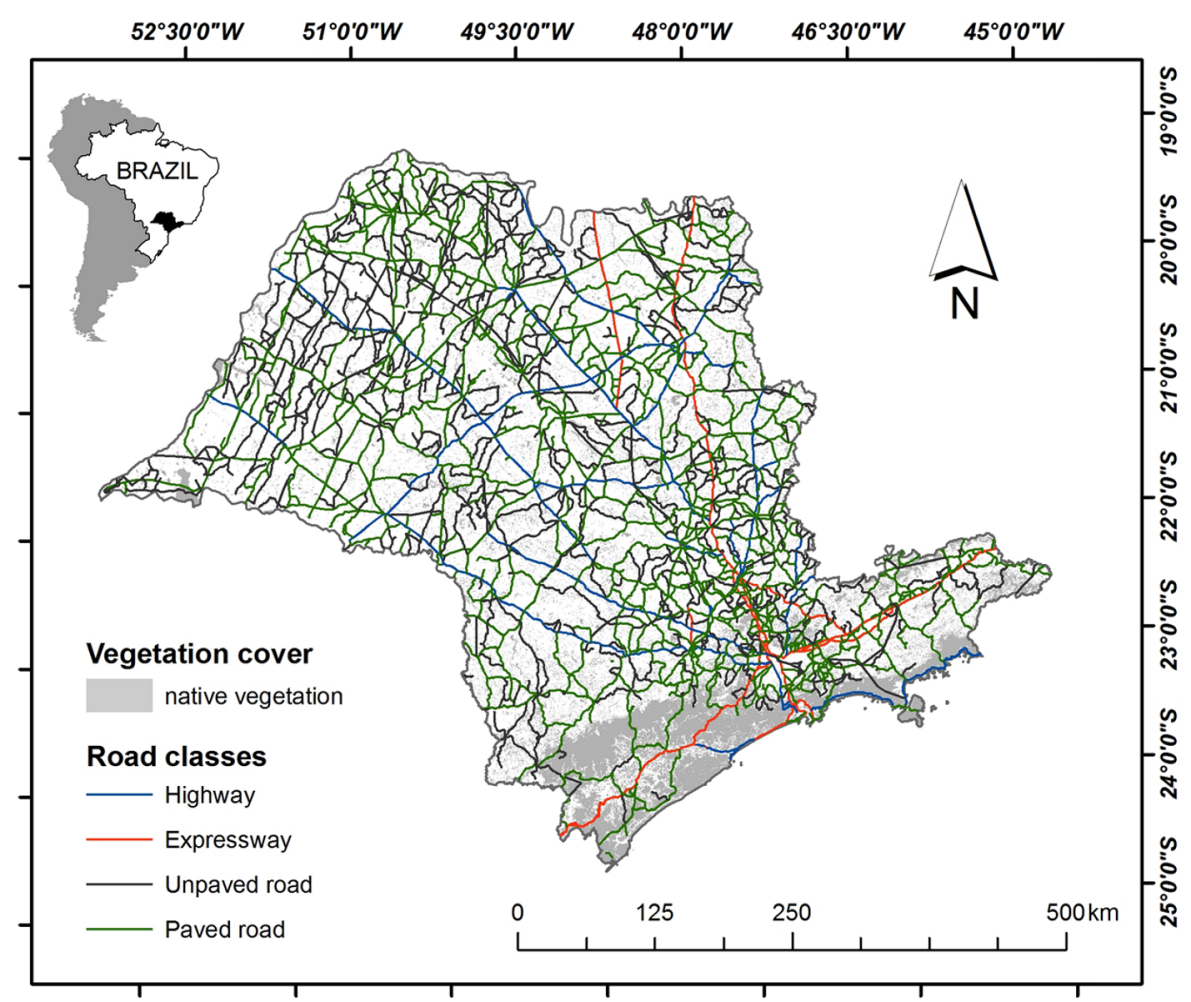

Figure 1. Study site showing the road network for the state of São Paulo with different road classes (coloured lines) and native vegetation (grey). Source data: IBGE 2010b, Kronka et al. 2005. 
All this urban sprawl of São Paulo was created to the detriment of massive areas of native vegetation. Nowadays, only $13.94 \%$ of extremely fragmented tropical forest (Atlantic Forest) and savannah (Brazilian Cerrado) formations (Rodrigues et al. 2008), two worldwide biodiversity hotspots (Myers et al.2000), remain in the state of São Paulo. Even with a rich biological diversity, only about $25 \%$ of the extant native vegetation in São Paulo State is legally protected within 236 heterogeneously distributed natural reserves (Rodrigues et al. 2008). About $80 \%$ of these protected areas are located in the Atlantic Forest domain and about $20 \%$ in the Cerrado. Because of the small amount of total protected area, almost $78 \%$ of the remaining native vegetation is located inside private properties and interspersed by several different land uses (Klink and Machado 2005, Durigan et al. 2007).

\section{Quantification of road density and vegetation cover}

To quantify the amount and density of roads in the study area, we used an official state road network map (IBGE 2010b; Figure 1) with four different road classes: unpaved roads, two-lane paved roads, highways (four-lane paved major roads) and expressways (at least eight-lane paved major roads; Figure 1). Due to the high regional heterogeneity of human occupation intensity, road type densities and vegetation cover throughout the state, we divided the study region according to 15 official subregions with similar socio-economic and geographical characteristics (Figure 2). This subdivision allowed us to better analyse and compare the local effects of roads on native vegetation according to the particularities of each place. We assessed native vegetation cover in the study region from a 1:20,000 scale map classified in seven vegetation types: Dense Moist Forest, Restinga (Coastal Shrubland), Mangrove, Wetland, Araucaria Moist Forest, Semidecidual Seasonal Forest and Savannah (Kronka et al. 2005). All this information was combined into a single Geographic Information System (ArcGIS Desktop 9.3.1).

To evaluate the relationship between vegetation cover and road distance, we used: 1) the official state road network map (IBGE 2010b; Figure 1) with all five different road classes; and, 2) the native vegetation cover map (scale of 1:20,000; Kronka et al. 2005; Figure 1). Around each road central axis, we created buffer zones of 10 different distances $(50,100,250$, $500,750,1000,1250,1500,1750$ and 2000 meters).

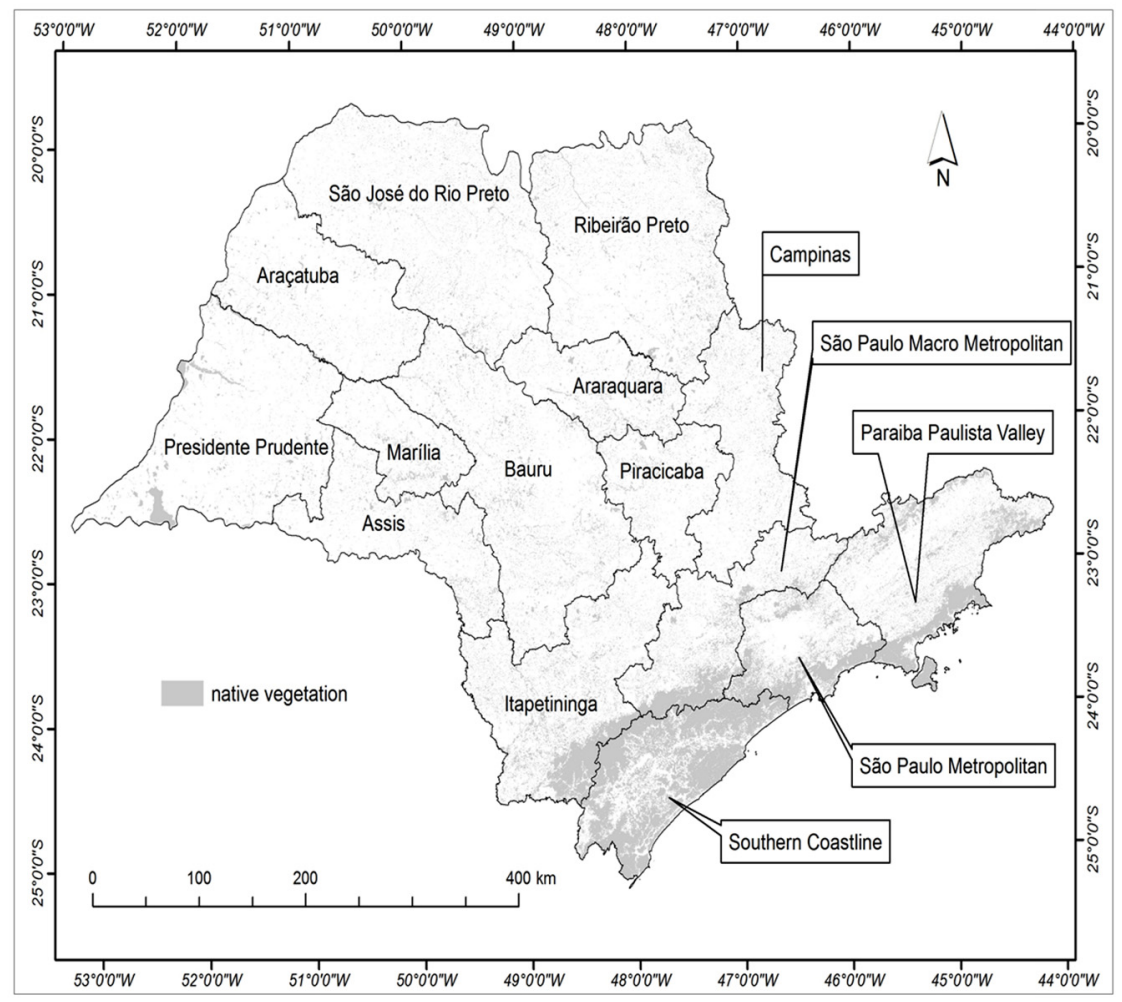

Figure 2. The 15 official subregions of the state of São Paulo. 
This was done individually for all road types: unpaved roads, two-lanes paved roads, highways and expressways. We quantified native vegetation cover within each buffer at two different levels, 1 - for all São Paulo state; and 2 - for each socio-economic subregion considered (Figure 2). All of this information was combined into a single Geographic Information System (ArcGIS Desktop 9.3.1). The relationship between vegetation cover and road distance for the whole state was analysed through the Pearson Correlation test for each road type, totalling 4 correlation values.

\section{Road-effect zone}

Road-effect zone (REZ) can be defined as the area along roads within the limits of the ecological effects on species, soil, and water, which can extend from meters to kilometers (Forman 2000). This zone was estimated using the methodology proposed by Forman (2000), who considered the shortest distance that negatively affects some sensitive temperate bird species (Reijnen et al. 1995) and compared it to roads classified based on paving status, road width and traffic intensity. Within this framework paved and wider roads with high traffic intensity are assumed to extend into wider and larger ecologically affected areas than unpaved and narrow roads with low traffic intensity. Because equivalent negative effects of roads on temperate birds (Reijnen et al. 1995) were also found for neotropical birds (Develey and Stouffer 2001, Laurance et al. 2004), we assumed that this categorical methodology would work in a similar way also for our study system.

We estimated all native vegetation and natural reserves within REZ for each subregion of the state of São Paulo using buffers of increasing distances according to each road type: unpaved roads - $200 \mathrm{~m}$; paved roads - $365 \mathrm{~m}$; highways $-810 \mathrm{~m}$; expressways - $1000 \mathrm{~m}$ (Forman 2000, Liu et al. 2008). We recognize that these distances are somehow arbitrarily set, since we found no trustworthy empirical information regarding the distance to which roads affect its surroundings in this region. Nevertheless, we believe that these distances represent a reasonable comparative road effect gradient which at least serves as a categorical surrogate which allows us to compare the presumed effect of each road type.

To standardise the conservation level of analysed reserves, we considered only those of fully environmental protection according to Brazilian laws and which were managed by the government (Rodrigues et al. 2008). In São Paulo State, most of these fully environmental protection reserves are in the Atlantic Forest biome $(97.27 \%$ in area $(8,410.6$ $\mathrm{km}^{2}$ ) and $71.67 \%$ in quantity) and only some are in the Cerrado $\left(2.73 \%\right.$ in area $\left(235.8 \mathrm{~km}^{2}\right)$ and $28.33 \%$ in quantity; Figure 3). The limits of the reserves were taken from an official vector conservation network map (IBGE 2010b). All analyses were done using the Patch Analyst 4 for ArcGIS (Rempel 2012).

\section{RESULTS}

Road density for the whole state of São Paulo (SP) was $0.151 \mathrm{~km} / \mathrm{km}^{2}$, varying from 0.068 to 0.253 $\mathrm{km} / \mathrm{km}^{2}$ within the state subregions (Figure 4). In SP, two-lane paved roads predominated $(50.0 \%$ of SP road density, $0.076 \mathrm{~km} / \mathrm{km}^{2}$ ), followed by unpaved roads $\left(36.2 \%, 0.055 \mathrm{~km} / \mathrm{km}^{2}\right)$, highways $(9.1 \%, 0.014$ $\left.\mathrm{km} / \mathrm{km}^{2}\right)$ and expressways $\left(4.7 \%, 0.007 \mathrm{~km} / \mathrm{km}^{2}\right)$. The same general tendency was observed for the subregions but with some variation: two-lane paved roads $\left(\right.$ mean $=0.079 \mathrm{~km} / \mathrm{km}^{2}, \mathrm{SD}=0.0253 \mathrm{~km} / \mathrm{km}^{2}$ ), unpaved roads $($ mean $=0.054, \mathrm{SD}=0.0189)$, highways (mean $=0.015, \mathrm{SD}=0.0068)$ and expressways (mean $=0.009, \mathrm{SD}=0.0129)$. The most dense road network was found in the São Paulo Metropolitan area (SPM, $0.253 \mathrm{~km} / \mathrm{km}^{2}$ ), followed by Campinas $\left(0.207 \mathrm{~km} / \mathrm{km}^{2}\right)$, Piracicaba $(0.204 \mathrm{~km} /$ $\mathrm{km}^{2}$ ), São Paulo Macro Metropolitan area (SPMM, $\left.0.191 \mathrm{~km} / \mathrm{km}^{2}\right)$, São José do Rio Preto $(0.180 \mathrm{~km} /$ $\left.\mathrm{km}^{2}\right)$, Araçatuba $\left(0.160 \mathrm{~km} / \mathrm{km}^{2}\right)$ and Araraquara $\left(0.160 \mathrm{~km} / \mathrm{km}^{2}\right.$; Figures 2 and 4$)$. The Southern Coastline had the lowest total road density $(0.068$ $\mathrm{km} / \mathrm{km}^{2}$ ), but with the second highest expressway density $\left(0.022 \mathrm{~km} / \mathrm{km}^{2}\right)$, only lower than SPM $(0.047$ $\left.\mathrm{km} / \mathrm{km}^{2}\right)$.

For the entire state of São Paulo (SP), there was more native vegetation cover farther from expressways $(r=0.7697$ and $p=0.009$; Figure 5). The other road types had weaker effects of road distances on the relative amount of remaining vegetation (Figure 5), slightly peaking between 750 and $1000 \mathrm{~m}$ from highways. The positive relationship between distance to roads and vegetation cover was most noticeable for expressways of the Southern Coastline subregion and SPM (Figure 6), which is highly covered by Dense Moist Forest despite its huge urban sprawl. 


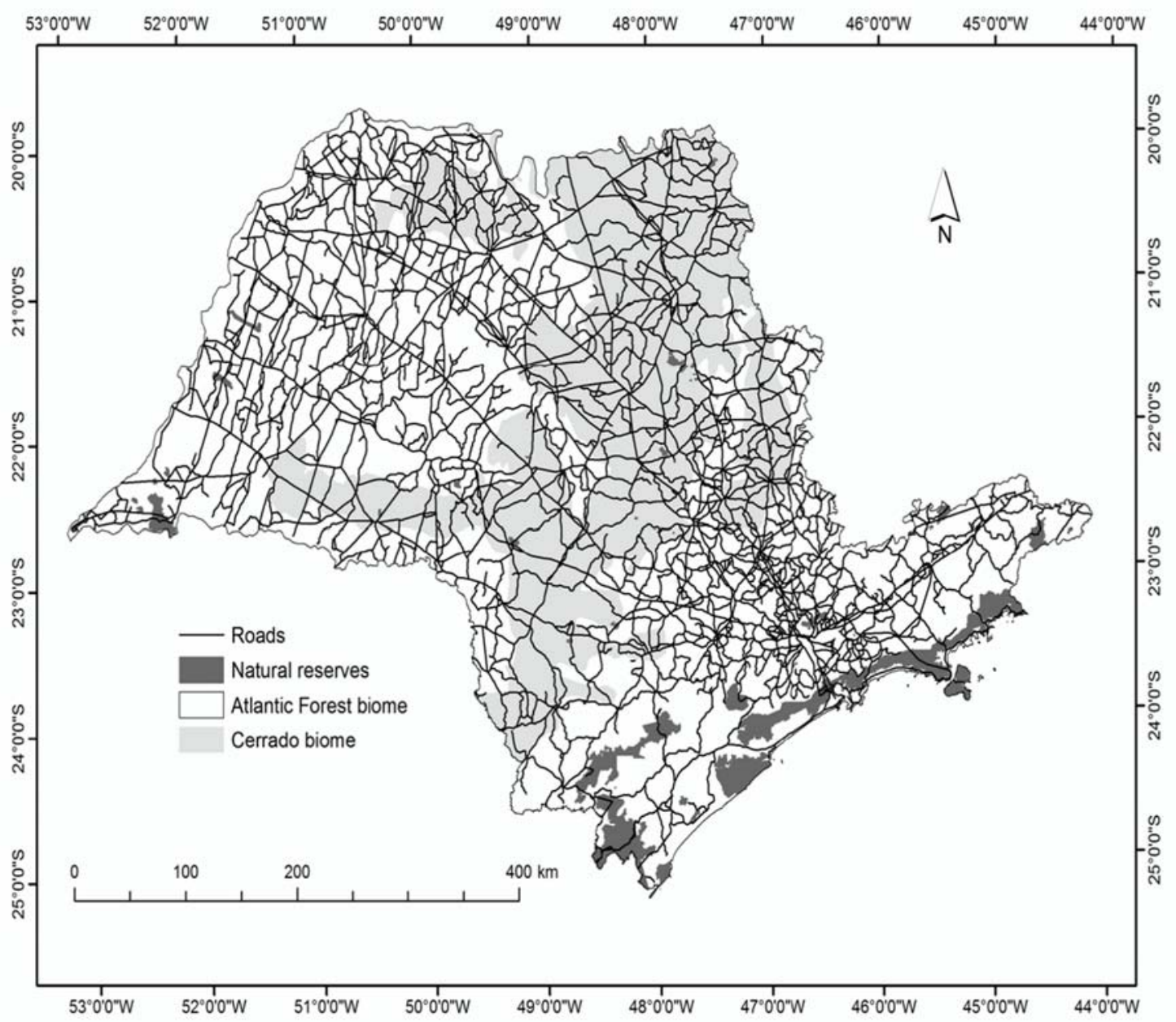

Figure 3. Natural reserves of integral environmental protection (black), Cerrado biome (grey) and Atlantic Forest biome (white) in the state of São Paulo.

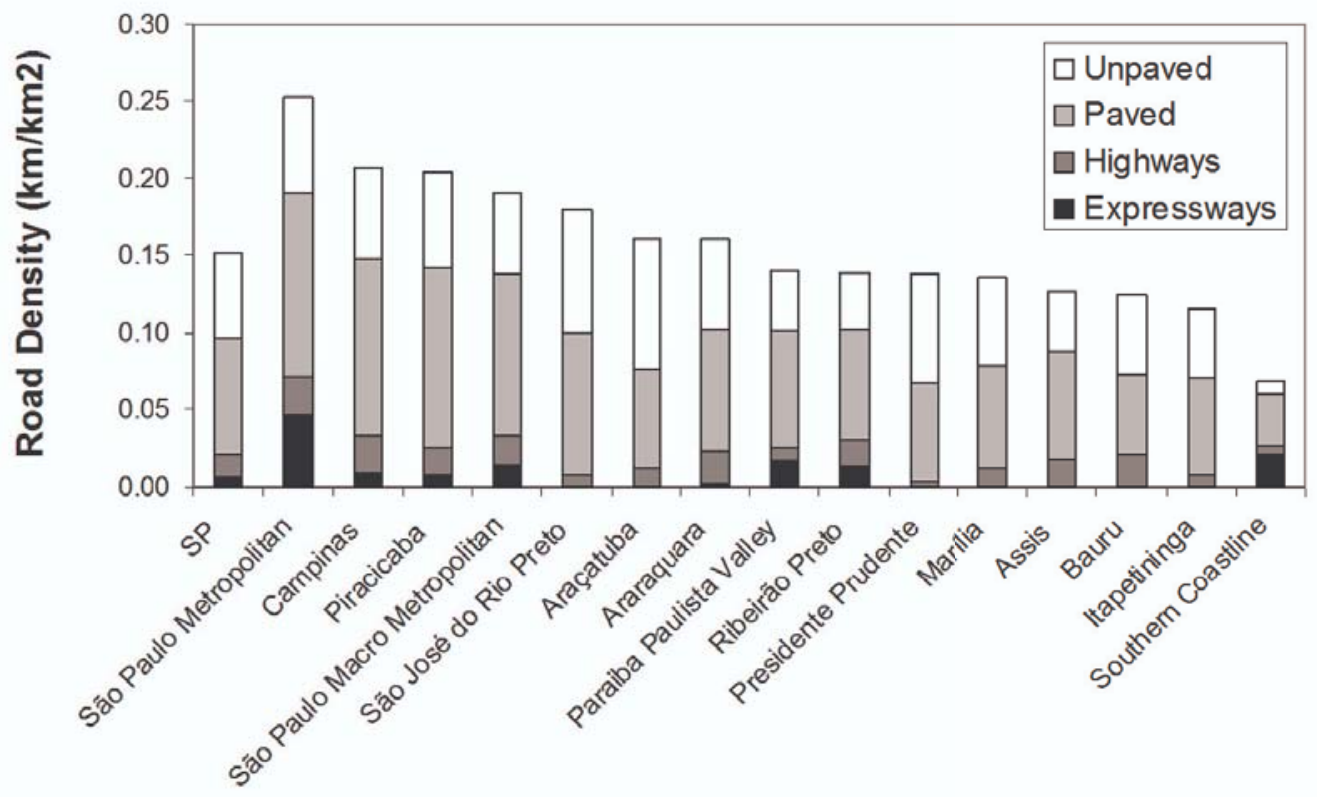

SP and Subregions

Figure 4. Road density, for each road type, in the subregions and in the entire São Paulo State (SP). 


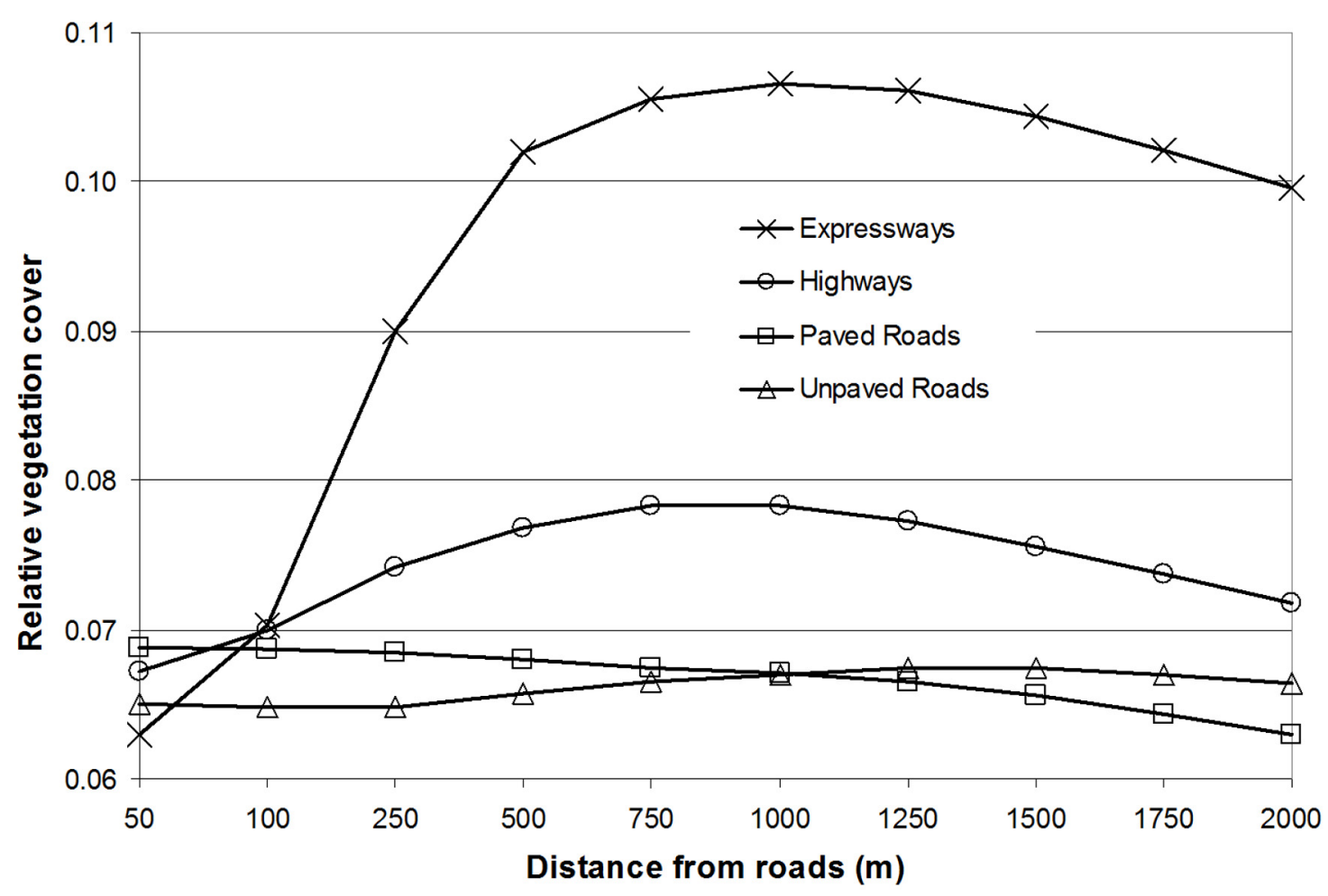

Figure 5. The relative amount of remaining vegetation in different distances from roads for each road type in the whole state.

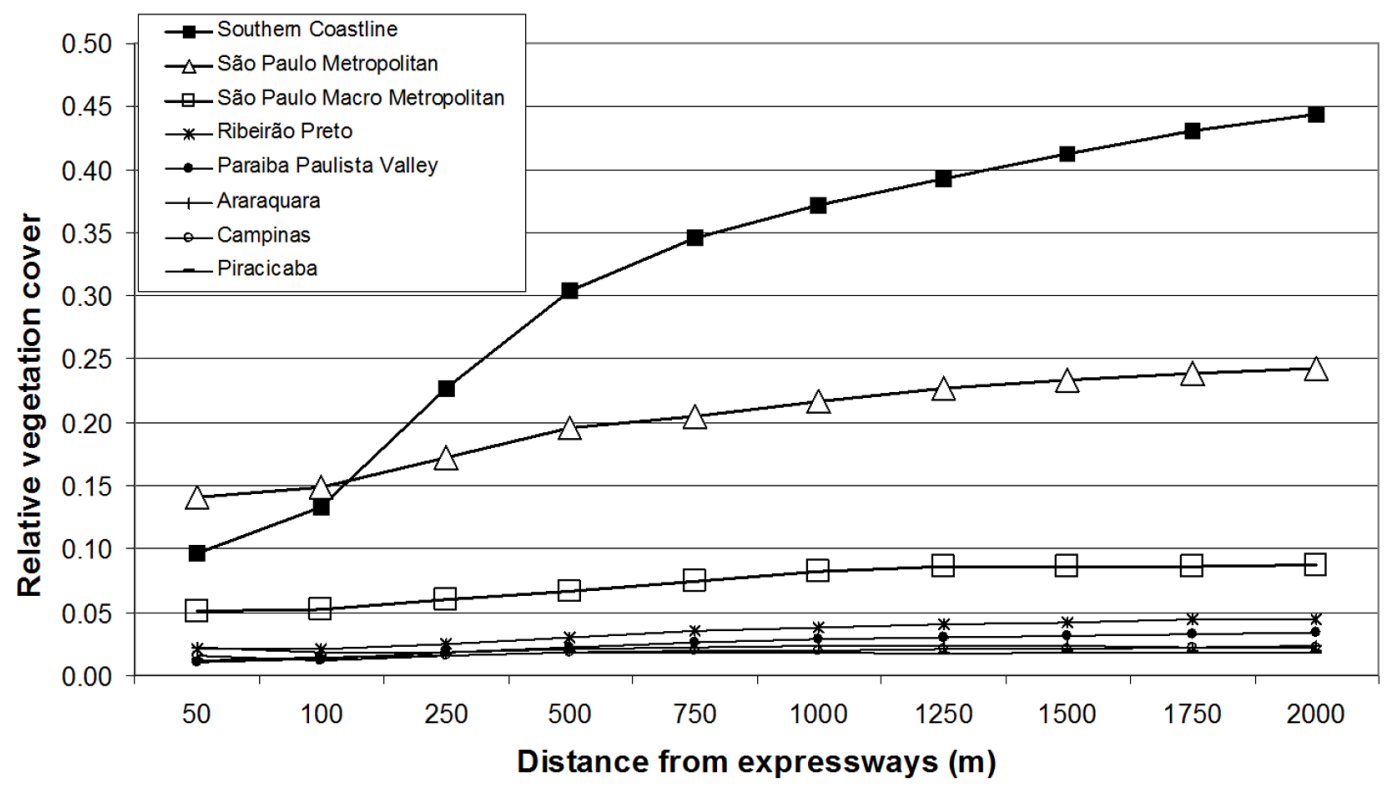

Figure 6. The relative amount of remaining vegetation in different distances from expressways for each subregion.

\section{Road-effect zones}

Almost 10\% (2,375,605 ha) of SP was within our pre-defined REZ. The most remote site from roads is covered by Dense Humid Forest, near Intervales State Park in the Southern Coastline, about $24 \mathrm{~km}$ far from roads $\left(24^{\circ} 22^{\prime} 41^{\prime \prime} \mathrm{S}, 48^{\circ} 17^{\prime} 45^{\prime \prime} \mathrm{W}\right)$. Paved roads affected $4.7 \%$ of the state, more than unpaved roads $(2.2 \%)$, highways $(1.5 \%)$ and expressways $(1.2 \%)$, following the same tendency of road density. About $6 \%\left(2,217.6 \mathrm{~km}^{2}\right)$ of the remaining native vegetation was within REZ, mainly due to twolane paved roads. All subregions had their vegetation affected by more than one type of roads, but SPM and the Southern Coastline subregion showed a high effect of expressways (Figure 7). 
However, seven subregions had more vegetation within REZ than the whole state; SPM (15.4\%), Campinas (9.1\%), Piracicaba (7.7\%), São José do Rio Preto (7.1\%), Paraiba Paulista Valley (7.0\%), Araçatuba (6.6\%), and SPMM (6.6\%; Figure 7).

The most affected vegetation type was Dense Humid Forest (51\% of all pre-defined REZ, Table 1), not only because it is the most dominant native vegetation type in SP, but also due to the proximity of the largest Dense Humid Forest remnants to the most dense road network in the study region, the SPM. On the other hand, if we consider the proportion of each vegetation type individually, the coastal formations (Mangroves and Coastal shrublands) were the most affected by roads (Table 1 ).

More than $10 \%\left(523.0 \mathrm{~km}^{2}\right)$ of the reserves were within REZ, mainly affected by expressways $(5.4 \%$ of entire state; Figure 8). Three subregions had more road affected reserves than the whole state: Assis (26.1\%) and Bauru (14.0\%), both due to highways; and SPM (11.9\%), where expressways cut through the largest State parks of SP. The impact of unpaved roads affecting reserves in Campinas (4.2\%), Araçatuba (3.9\%), and Bauru (3.3\%; Figure 8) subregions is also notable.

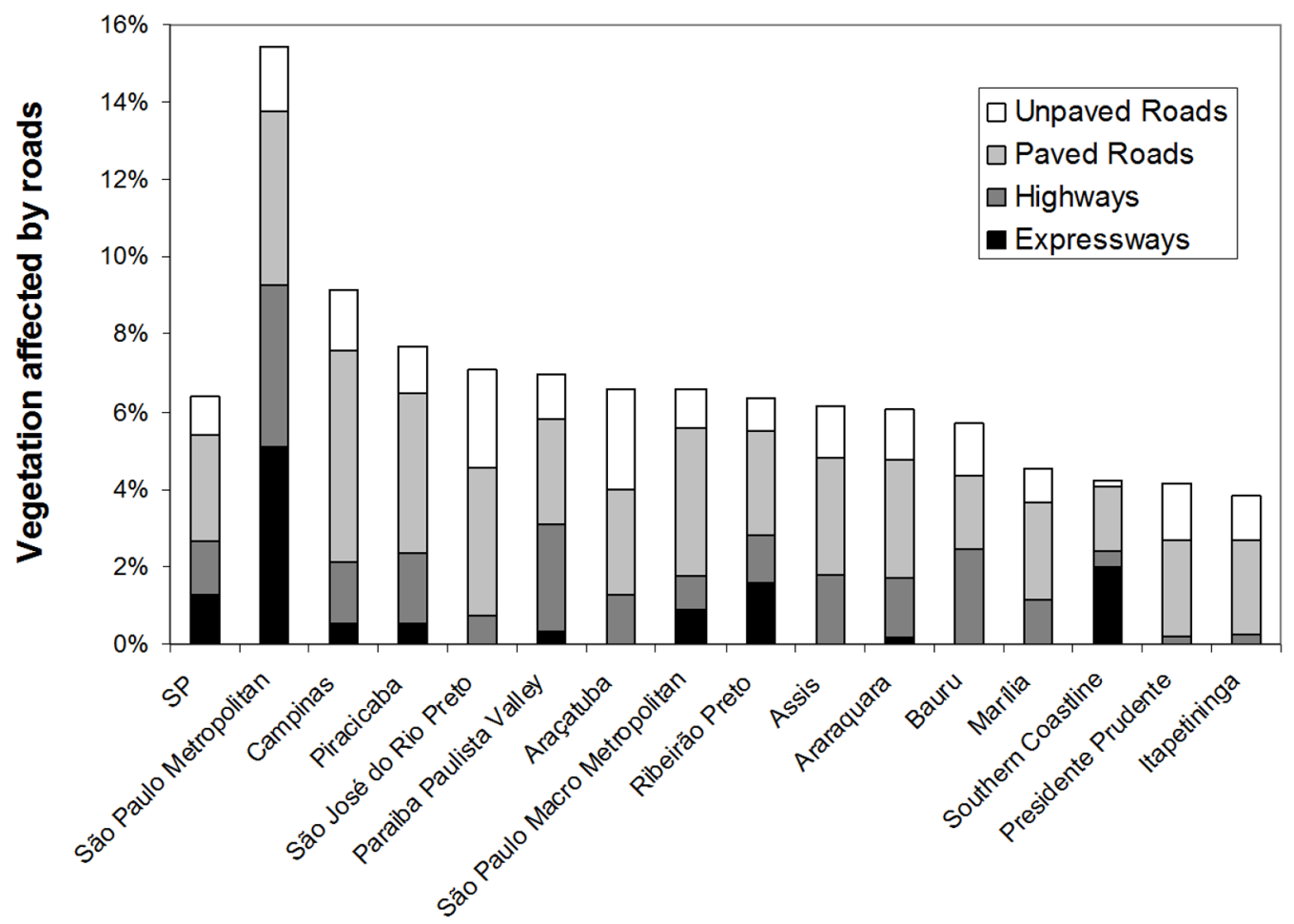

SP and Subregions

Figure 7. Vegetation affected by roads, for each road type, in the subregions and in the entire São Paulo State (SP).

Table 1. Proportion of each vegetation type ecologically affected by roads for all São Paulo State.

\begin{tabular}{lcc}
\hline \hline VEGETATION TYPES & $\begin{array}{c}\text { PROPORTION OF AREA ECOLOGICALly } \\
\text { AFFECTED BY ROADS IN RELATION TO } \\
\text { TERITORY AREA }\end{array}$ & $\begin{array}{c}\text { PROPORTION OF AREA ECOLOGICALLY } \\
\text { AFFECTED BY ROADS IN RELATION TO } \\
\text { VEGETATION TYPE AREA }\end{array}$ \\
\hline \hline Dense Moist Forest & $51.0 \%$ & $6.2 \%$ \\
Semidecidual Seasonal Forest & $8.3 \%$ & $5.1 \%$ \\
Savanna & $5.8 \%$ & $6.5 \%$ \\
Restinga & $4.6 \%$ & $8.7 \%$ \\
Wetland & $4.5 \%$ & $4.1 \%$ \\
Araucaria Moist Forest & $3.0 \%$ & $3.9 \%$ \\
Mangrove & $0.6 \%$ & $15.6 \%$ \\
\hline \hline
\end{tabular}


Thirty-one reserves (52.54\% in number) were within REZ: 20 in the Atlantic Forest and 11 in the Cerrado (Figures 3 and 9). This means that $64.7 \%$ of the reserves located in the Cerrado of São Paulo are within REZ, compared to $46.5 \%$ of the reserves located in the Atlantic Forest. Three of these reserves have more than $60 \%$ of their territory within REZ; two in the Cerrado (Figure 9). Some are only or mostly affected by expressways (Jaraguá, Vassununga, Valinhos and Jacupiranga), others are only or mostly affected by highways (Assis, Santa Bárbara, Cantareira), but most are essentially affected by twolane paved roads (Figure 9). Particularly, Jaraguá State Park is surrounded by three expressways: Anhanguera (SP-330), Bandeirantes (SP-348) and Rodoanel Mário Covas (SP-021).

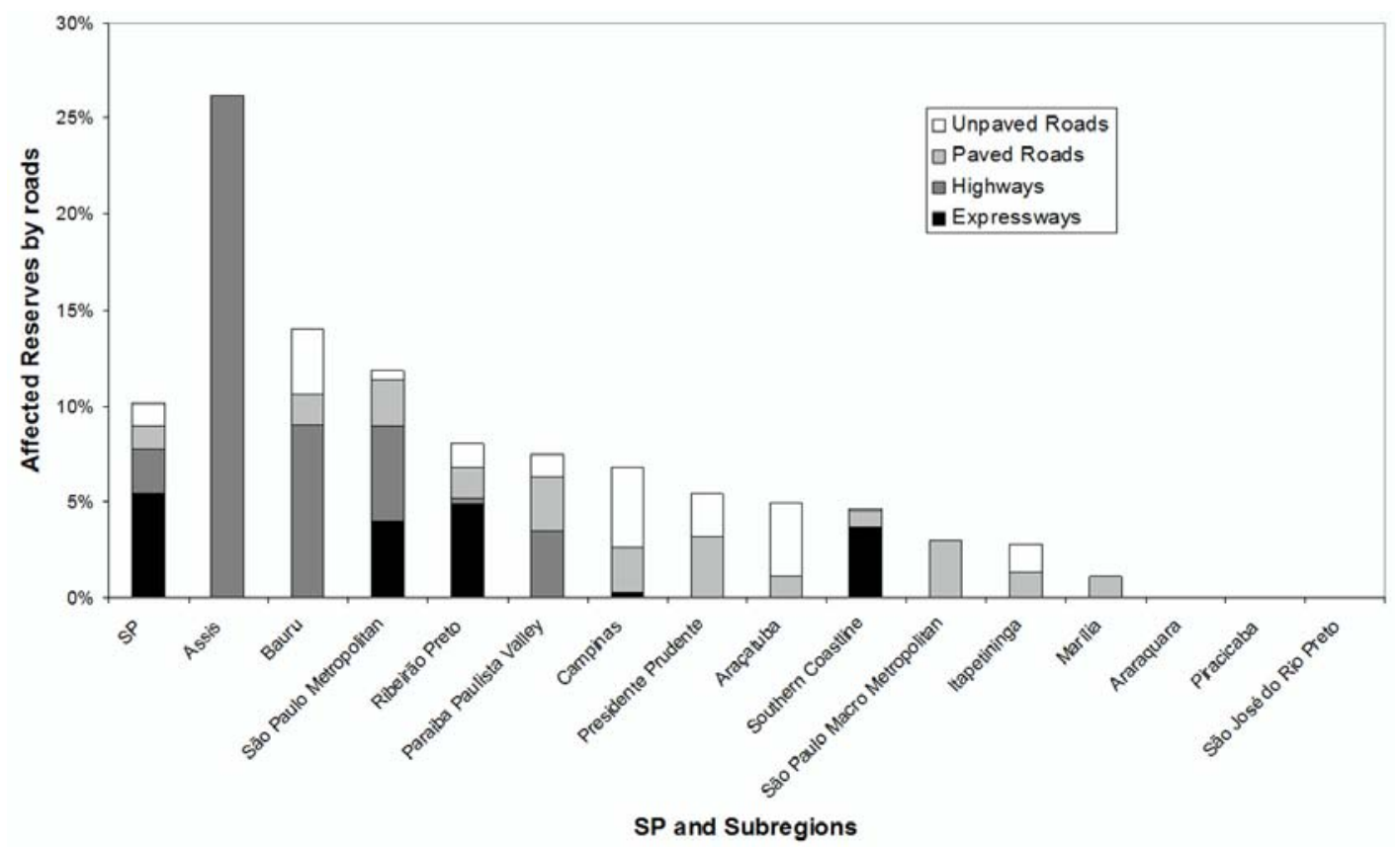

Figure 8. Relative area of reserves affected by roads in each subregion and all São Paulo State.

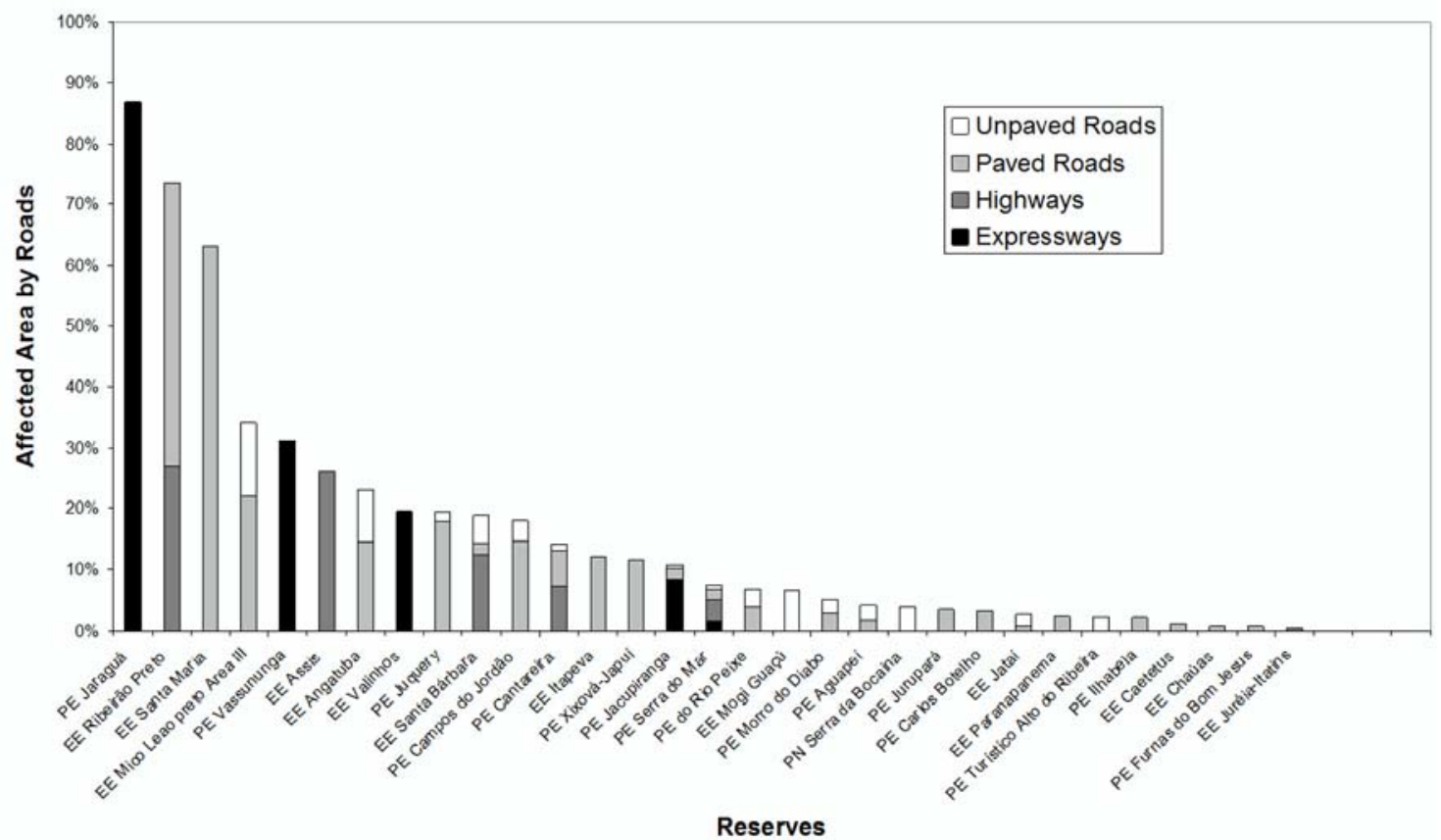

Figure 9. Proportion affected area by each road type for 31 reserves of São Paulo State, where: R. E. = State Reserve, E. Ec. = Ecological Station, P. E. $=$ State Park, PARNA $=$ National Park, P. Ec. $=$ Ecological Park. 


\section{DISCUSSION}

Road density is an indicator of the potential impact of roads on local environments (Forman et al. 2003). In our studied region, the most densely populated subregions, such as SPM, Campinas and Piracicaba, have higher road density than midwestern North American states (La Rue and Nielsen 2008), but lower than the whole USA or many European countries (Forman et al. 2003, Huijser and Clevenger 2006). It is also important to note that São Paulo state has a road density higher than the mean of Brazilian states (mean $=0.111 \mathrm{~km} / \mathrm{km}^{2}, \mathrm{SD}=0.064 \mathrm{~km} / \mathrm{km}^{2}$ ), varying from $0.003 \mathrm{~km} / \mathrm{km}^{2}$ (Amazonas State) to $0.263 \mathrm{~km} /$ $\mathrm{km}^{2}$ (Federal District State), and higher than the whole country $\left(0.067 \mathrm{~km} / \mathrm{km}^{2}\right)$. Overall, the increasing vegetation cover further from roads is probably because of more intense human occupation near transportation networks due to easier access to areas along roads (Nagendra et al. 2003).

In pristine tropical regions, roads usually facilitate the establishment of human settlements, mining facilities and increased hunting, a process, which threatens conservation called the "the Pandora's box effect" (Laurance et al. 2009). This typically occurs in the Amazon, where approximately $95 \%$ of all forest clearings take place at a maximum distance of $50 \mathrm{~km}$ from roads, in other words, deforestation is higher near roads (Ferreira et al. 2005, Laurance et al. 2009, Barni et al. 2012). Similarly, the Southern Coastline of São Paulo showed a stronger positive relation between forest cover and distance to roads, where native vegetation cover increased at larger distances from expressways up to $500 \mathrm{~m}$, where a maximum land cover level was reached. There, roads mainly follow the central axis of the narrow and elongated coastal planes limited by the ocean to the south-east and very high (up to $1600 \mathrm{~m}$ ) and steep mountains to the north-west, where most of the remaining Dense Moist Forest in the state occurs. This configuration increases road effects because no place is really far from roads, with the most remote site being $24 \mathrm{~km}$ far from roads and may be interesting for evaluating the effect of roadless areas on biodiversity in tropical forests (Strittholt and Dellasala 2001, Chen and Roberts 2008, Selva et al. 2011). Landscapes with road density up to $0.079 \mathrm{~km} / \mathrm{km}^{2}$, such as the Southern Coastline, may allow cougar movement and may be used as dispersal corridors. Nevertheless, higher densities tend to hinder their dispersion or increase road-kill risk (La Rue and Nielsen 2008, Colchero et al. 2011). This region actually has a low road density $\left(0.068 \mathrm{~km} / \mathrm{km}^{2}\right)$ and large cougar populations (Martins et al. 2008), but the higher expressway density found in this subregion may increase road-kill risk for cougars and other endangered species (Miotto et al. 2012) if no mitigating actions are taken.

When considering the whole state, while most roads were built after most deforestation had occurred, these linear infrastructures may still exist as permanent scars on the landscape, facilitating more recent deforestation. In the last 50 years, increased accessibility and consequent land appreciation in São Paulo led high valued suburban real-estate and industrial areas grow around larger cities, presently driving land-use and land-cover dynamics in the region (Freitas et al. 2010). In this way, even if constructed after deforestation processes took place, roads still may affect the spatial distribution of native vegetation and the efficiency of many conservation reserves due to more intense human proximity. About $14 \%$ of native vegetation remains in São Paulo State (Rodrigues et al. 2008) and about half of it were within REZ.

Dense Moist Forest was the most road-affected vegetation type in the state because of its higher land coverage and proximity to the largest urban areas. However, although less affected by roads when considering the absolute area count, coastal environments such as Mangroves and Coastal shrublands are very close to high traffic roads. These are extremely endangered environments and both are restricted to a narrow region along the seashore, where there is dense human population and many expressways with intense traffic, such as BR-101 highway that connects Rio de Janeiro and Santos, where the largest South American seaport is located. Mangroves and Coastal shrub-lands are also threatened by coastal sprawl of low-density residential and commercial development scattered throughout large land areas of the coastal planes (Beach 2002, Furlan et al. 2011).

Laurance et al. (2009) attest that in tropical regions, unpaved roads have less impact than paved ones on vegetation and wildlife, as dirt roads tend to be located in inaccessible and remote places. However unpaved roads are still highly abundant in inner São Paulo, forming dense networks, especially when compared to high- and expressways, being the most 
influential roads in the state. Some northwestern subregions, such as São José do Rio Preto and Araçatuba, showed that the higher unpaved road density greatly contributed to road effects on native vegetation. In these regions, where relief is smoother than near the coastline, easy agricultural intensification generates more roads to grain production. This leads to smaller and more numerous patches due to higher deforestation rates (Dobrovolski et al. 2011). This may explain why the relation between roads and vegetation was weaker in these subregions far from the coast.

Despite the fact that the vegetation near the coastline, restingas and mangroves, is the most affected by roads, the reserves most affected by roads are in the interior of the state, mostly in the Cerrado domains. Even though this biome is considered a hotspot of biodiversity (Myers et al. 2000), it has less protected areas than the Atlantic Forest and most of these reserves are affected by roads in São Paulo state due to extensive land use for agriculture and livestock production (Dobrovolski et al. 2011), which also requires roads due to the necessity of distributing their commodities. High proximity to these roads reduces the efficiency of biodiversity protection reserves because of increased access for illegal hunting, harvesting, logging and human waste. These consequences of road effect may cause local extinction of more sensitive species due to edge effect or noise (Rheindt 2003, Van der Ree et al. 2011) and smaller populations due to increased mortality rates caused by diseases and vehicle collisions (Borda-de-Água et al. 2011, Roger et al. 2011) reducing species diversity. Reserves highly affected by roads are thus the most vulnerable to environmental degradation and consequently might have actual impaired conservation.

In tropical ecosystems, where it is harder to obtain a complete list of species because of high species diversity and high species turnover (Felinks et al. 2011), land cover and land use maps have been used in landscape level approaches, which take into account mostly the size and connectivity of remaining natural vegetation, to select conservation priority areas (Rodrigues et al. 2008, Gordon et al. 2009, Pinto and Grelle 2009). However, as roads had a negative association with vegetation cover and the literature has shown their damaging effects on wildlife, we believe that roads should also be included as an additional criterion for reserve selection. The effects of roads on native vegetation and natural reserves could be a tool for including roads in reserve design and management. There is also a need for more studies on the effect of roads on neotropical biota, so that better adjusted evaluation of road effects according to road type can be produced for this region. Also, such kind of studies should be demanded reserve in management plans in order to indicate more efficient planning and mitigation measures (Laurance et al. 2009). We propose that priority areas for fully conservation of pristine environments should include mostly remote areas, which are far from larger roads and under lower general road influence (Strittholt and Dellasala 2001, Chen and Roberts 2008, Rayn and Sutherland 2011), including unpaved road networks. If feasible, road removal to reduce network density (Switalski et al. 2004) is advisable. This could be accomplished by incorporating surrounding unpaved roads of lesser importance into reserve buffer zones, which could then be left for regrowth or used solely for reserve monitoring and maintenance.

On the other hand, reserves near roads or dense road networks should have alternative management strategies to reduce road effects. In addition to the commonly used establishment of wildlife road passages and similar structures (Beckmann et al.2010), what we propose is that in such cases in situ conservation should be combined with environmentally sustainable human use of native environments. Because several conservation problems caused by road nearness are strongly related to inappropriate human behavior in natural environments, such as illegal hunting and harvesting or squatter housing residue, associating reserve establishment and management with controlled recreational activities, which inhibit land misuse, could reduce some critical road effects.

The inclusion of roads as another factor to be considered in conservation priority decisions tends not to directly affect conservation site selection, since we believe that most native vegetation patches deserve proper conservation, especially in most tropical regions. What we propose is that road networks and road proximity should be used to augment, along with other already used indicators, the decision-making process of the most appropriate reserve type and management strategy at a given location. Our aim, by including roads as an additional criterion for reserve selection, is to enhance the actual protection of the ecosystem services of these areas and associated biota 
based not only on the area itself, but also explicitly considering the state of its surroundings.

ACKNOWLEDGMENTS. We are thankful to the anonymous reviewers for invaluable comments on this manuscript. This study was supported by FAPESP (Freitas' post-doctorate fellowship, Proc. 2006/026739). Jim Hesson of AcademicEnglishSolutions.com proofread the English.

\section{REFERENCES}

Barni, P. E., P. M. Fearnside, and P. M. L. A. Graça. 2012. Desmatamento no sul do Estado de Roraima: padrões de distribuição em função de Projetos de Assentamento do INCRA e da distância das principais rodovias (BR-174 e BR-210). Acta Amazonica 42:195-204.

Beach, D. 2002. Coastal sprawl: The effects of urban design on aquatic ecosystems in the United States. Pew Oceans Commission, Arlington.

Beckmann, J. P., A. P. Clevenger, M. P. Huijser, and J. A. Hilty. 2010. Safe passages: highways, wildlife, and habitat connectivity. Island Press, Washington.

Borda-de-Água, L., L. Navarro, C. Gavinhos, and H. M. Pereira. 2011. Spatio-temporal impacts of roads on the persistence of populations: analytic and numerical approaches. Landscape Ecology 26:253-265.

Chen, X. and K. A. Roberts. 2008. Roadless areas and biodiversity: a case study in Alabama, USA. Biodiversity and Conservation 17:2013-2022.

Colchero, F., D. A. Conde, C. Manterola, C. Chávez, A. Rivera, and G. Ceballos. 2011. Jaguars on the move: modeling movement to mitigate fragmentation from road expansion in the Mayan Forest. Animal Conservation 14:158-166.

Develey, P. F. and P. C. Stouffer. 2001. Effects of roads on movements by understory birds in mixed-species flocks in central Amazonian Brazil. Conservation Biology 15:1416-1422.

Dobrovolski, R., J. A. F. Diniz-Filho, R. D. Loyola, and P. De Marco Jr. 2011. Agricultural expansion and the fate of global conservation priorities. Biodiversity and Conservation 20:2445-2459.

Dramstad, W. E., J. D. Olson, and R. T. T. Forman. 1996. Landscape ecology principles in landscape architecture and landuse planning. Island Press, Washigton.

Drummond, J. 2004. Brazil. Pages 161-169 in S. Krech III, J. R. McNeill, and C. Merchant. Encyclopedia of World Environmental History. Routledge, New York.

Durigan, G., M. F. Siqueira, and G. A. D. C. Franco. 2007. Threats to the cerrado remnants of the state of São Paulo, Brazil. Scientia Agricola 64:355-363.

Fahrig, L. and T. Rytwinski. 2009. Effects of roads on animal abundance: an empirical review and synthesis. Ecology and Society 14:21.

Felinks, B., R. Pardini, M. Dixo, K. Follner, J. P. Metzger, and K. Henle. 2011. Effects of species turnover on reserve site selection in a fragmented landscape. Biodiversity and Conservation 20:1057-1072.

Ferreira, L. V., E. M. Venticinque, and S. Almeida. 2005. O desmatamento na Amazônia e a importância das áreas protegidas. Estudos Avançados 19:157-166.
Forman, R. T. T. 2000. Estimate of the area affected ecologically by the road system in the United States. Conservation Biology 14:31-35.

Forman, R. T. T. and R. D. Deblinger. 2000. The ecological road-effect zone of a Massachusetts (U.S.A.) suburban highway. Conservation Biology 14:36-46.

Forman, R. T. T., D. Sperling, J. A. Bissonette, A. P. Clevenger, C. D. Cutshall, V. H. Dale, L. Fahrig, R. France, C. R. Goldman, K. Heanue, J. A. Jones, F. J. Swanson, T. Turrentine, and T. C. Winter. 2003. Road ecology: science and solutions. Island Press, Washington.

Freitas, S. R., M. M. Alexandrino, R. Pardini, and J. P. Metzger. 2012. A model of road effect using line integrals and a test of the performance of two new road indices using the distribution of small mammals in an Atlantic Forest landscape. Ecological Modelling 247:64-70.

Freitas, S. R., T. J. Hawbaker, and J. P. Metzger. 2010. Effects of roads, topography, and land use on forest cover dynamics in the Brazilian Atlantic Forest. Forest Ecology and Management 259:410-417.

Furlan, A., D. M. Bonotto, and S. J. Gumiere. 2011. Development of environmental and natural vulnerability maps for Brazilian coastal at São Sebastião in São Paulo State. Environmental Earth Sciences 64:659-669.

Gordon, A., D. Simondson, M. White, A. Moilanen, and S. A. Bekessy. 2009. Integrating conservation planning and landuse planning in urban landscapes. Landscape and Urban Planning 91:183-194.

Huijser, M. P. and A. P. Clevenger. 2006. Habitat and corridor function of righ-of-way. Pages 233-254 in J. Davenport and J. L. Davenport. The ecology of transportation: managing, mobility for the environment. Springer, Dordrecht.

IBGE. 2010a. Censo demográfico 2010. Available at: www.ibge.gov.br

IBGE. 2010b. Base vetorial contínua da carta internacional do mundo ao milionésimo (BCIM). Available at: www.ibge.gov.br

Klink, C. A. and R. B. Machado. 2005. A conservação do Cerrado brasileiro. Megadiversidade 1:147-155.

Kronka, F. J. N., M. A. Nalon, C. K. Matsukuma, M. M. Kanashiro, M. S. S. Ywane, M. Pavão, G. Durigan, L. M. P. R. Lima, J. R. Guillaumon, J. B. Baitello, S. C. Borgo, L. A. Manetti, A. M. F. Barradas, J. C. Fukuda, C. N. Shida, C. H. B. Monteiro, A. A. S. Pontinha, G. G. Andrade, O. Barbosa, and A. P. Soares. 2005. Inventário florestal da vegetação natural do Estado de São Paulo. Secretaria do Meio Ambiente; Instituto Florestal, São Paulo.

LaRue, M. A. and C. K. Nielsen. 2008. Modelling potential dispersal corridors for cougars in midwestern North America using least-cost path methods. Ecological Modelling 212:372-381.

Laurance, S. G., P. C. Stouffer, and W. F. Laurance. 2004. Effects of road clearings on movement patterns of understory rainforest birds in Central Amazonia. Conservation Biology 18:1099-1109.

Laurance, W. F., M. Goosem, and S. G. W. Laurance. 2009. Impacts of roads and linear clearings on tropical forests. Trends in Ecology and Evolution 24:659-669.

Liu, S. L., B. S. Cui, S. K. Dong, Z. F. Yang, M. Yang, and K. Holt. 2008. Evaluating the influence of road networks on landscape and regional ecological risk - A case study in Lancang River Valley of Southwest China. Ecological Engineering 34:91-99.

Martins, R., J. Quadros, and M. Mazzolli. 2008. Hábito 
alimentar e interferência antrópica na atividade de marcação territorial do Puma concolor e Leopardus pardalis (Carnivora: Felidae) e outros carnívoros na Estação Ecológica de Juréia-Itatins, São Paulo, Brasil. Revista Brasileira de Zoologia 25:427-435.

McGregor, R. L., D. J. Bender, and L. Fahrig. 2008. Do small mammals avoid roads because of the traffic? Journal of Applied Ecology 45:117-123.

Miotto, R. A., M. Cervini, R. A. Begotti, and P. M. Galetti Jr. 2012. Monitoring a puma (Puma concolor) population in a fragmented landscape in southeast Brazil. Biotropica 44:98-104.

Murcia, C. 1995. Edge effects in fragmented forests: implications for conservation. Trends in Ecology and Evolution 10:58-62.

Myers, N., R. A. Mittermeier, C. G. Mittermeier, G. A. B. Fonseca, and J. Kent. 2000. Biodiversity hotspots for conservation priorities. Nature 403:853-858.

Nagendra, H., J. Southworth, and C. Tucker. 2003. Accessibility as a determinant of landscape transformation in western Honduras: linking pattern and process. Landscape Ecology 18:141-158.

Neto, O. L. 2001. Transportes no Brasil: história e reflexões. Empresa Brasileira de Planejamento de Transportes/ GEIPOT, Brasília.

Pinto, M. P. and C. E. V. Grelle. 2009. Seleção de reservas: estudos na América do Sul e revisão de conceitos. Oecologia Brasiliesis 13:498-517.

Rayn, D. and W. J. Sutherland. 2011. Impact of nature reserve establishment on deforestation: a test. Biodiversity and Conservation 20:1625-1633.

Reijnen, R., R. Foppen, C. Ter Braak, and J. Thissen. 1995. The effects of car traffic on breeding bird populations in woodland. III. Reduction of density in relation to the proximity of main roads. Journal of Applied Ecology 32:187-202.
Rempel, R. S., D. Kaukinen, and A. P. Carr. 2012. Patch Analyst and Patch Grid. Ministry of Natural Resources/Centre for Northern Forest Ecosystem Research, Thunder Bay. Available at: http://www.cnfer.on.ca/SEP/patchanalyst/

Rheindt, F. E. 2003. The impact of road on birds: Does song frequency play a role in determining susceptibility to noise pollution? Journal of Ornithology 144:295-306.

Rodrigues, R. R., C. A. Joly, M. C. W. Brito, A. Paese, J. P. Metzger, L. Casatti, M. A. Nalon, N. Menezes, N. M. Ivanauskas, V. Bolzani, and V. L. R. Bononi. 2008. Diretrizes para conservação e restauração da biodiversidade no estado de São Paulo. Instituto de Botânica, São Paulo.

Roger, E., S. W. Laffan, and D. Ramp. 2011. Road impacts a tipping point for wildlife populations in threatened landscapes. Population Ecology 53:215-227.

Selva, N., S. Kreft, V. Kati, M. Schluck, B. G. Jonsson, B. Mihok, H. Okarma, and P. L. Ibisch. 2011. Roadless and lowtraffic areas as conservation targets in Europe. Environmental Management 48:865-877.

Strittholt, J. R. and D. A. Dellasala. 2001. Importance of roadless areas in biodiversity conservation in forested ecosystems: case study of the Klamath-Siskiyou ecoregion of the United States. Conservation Biology 15:1742-1754.

Switalski, T. A., J. A. Bissonette, T. H. DeLuca, C. H. Luce, and M. A. Madej. 2004. Benefits and impacts of road removal. Frontiers in Ecology and the Environment 2:21-28.

Taylor, P. D., L. Fahrig, K. Henein, and G. Merriam. 1993. Connectivity is a vital element of landscape structure. Oikos 68:571-573.

Van der Ree, R., J. A. G. Jaeger, E. A. Van der Grift, and A. P. Clevenger. 2011. Effects of roads and traffic on wildlife populations and landscape function: Road Ecology is moving toward larger scales. Ecology and Society 16:48. 